\title{
Performance of an improved breed of common carp - Amur (Hungarian strain) in the North-eastern hill state of Meghalaya, India
}

\author{
S. K. DAS \\ Division of Fisheries, ICAR Research Complex for NEH Region, Umiam, Umroi Road, Barapani -793 103 \\ Meghalaya, India \\ e-mail: skdas01@yahoo.com
}

\begin{abstract}
Common carp (Cyprinus carpio Linnaeus, 1758) is an important fish species for aquaculture in the North-east hill region (NEH) of India. However, in recent years, the growth performance of the existing stock of common carp has been a major concern. In an effort to improve fish production from farmers' ponds and to evaluate the performance of the breed in mid hill condition, a genetically improved breed of common carp, Amur (Hungarian strain) was introduced in Meghalaya in 2010. Fingerlings of Amur common carp (weight $\sim 14.5 \mathrm{~g}$ and length $\sim 10.5 \mathrm{~cm}$ ), reared under mid-altitude conditions in the fish farm of the ICAR Research Complex for North-eastern hill (NEH) Region, Barapani, Meghalaya, attained maturity in about 14 months period. The first breeding trial with this newly introduced variety was conducted successfully in March 2011 when the atmospheric temperature ranged between $16.0-18.3^{\circ} \mathrm{C}$. The fertilised eggs hatched in $78-83 \mathrm{~h}$ (water temperature $19.0-22.8^{\circ} \mathrm{C}$ and $\mathrm{pH}$ 6.5-6.8). Three year studies revealed that the performance of Amur common carp is superior over the local existing breed in farmers ponds under the mid hill conditions.
\end{abstract}

Keywords: Amur common carp, Breeding, Growth, On-farm trial

\section{Introduction}

The North-east region of India comprising the states of Arunachal Pradesh, Assam, Manipur, Meghalaya, Mizoram, Nagaland, Sikkim and Tripura is blessed with rich biodiversity and fisheries resources. With more than $90 \%$ of the population being fish eaters (Das and Ngachan, 2014), there is always a growing demand for fish. However, there exists a wide gap between supply and demand resulting in shortage of fresh fish. The state of Meghalaya produces about $7500 \mathrm{t}$ of freshwater fish annually against an annual requirement of about 33,000 $\mathrm{t}$ (Anon, 2012). To meet the growing requirement, the state imports freshwater fish mostly from Andhra Pradesh, West Bengal and neighbouring Assam.

While several fish species are found in the natural waters of the region, presently only about 10-12 food fish species are being cultured by the fish farmers of the North-eastern region. Since the Indian major carps (IMCs) do not perform very well in hill aquaculture, there is a need to find alternate candidate fish species which can grow well in shorter period of time.

Among all the cultured species; silver carp (Hypophthalmichthys molitrix), grass carp (Ctenopharyngodon idella) and common carp (Cyprinus carpio) perform better in composite culture system in the mid altitude conditions. Further, the two indigenous minor carps, Labeo gonius and
Labeo bata were also found to perform better than the IMCs (Das et al., 2010).

The common carp is an important fish species of the region, which is mostly grown together with IMCs in polyculture systems. Although the best growth is obtained at water temperature of $23-30^{\circ} \mathrm{C}$, the fish can survive cold winter periods making it one of the most suitable fish species for hill aquaculture in the North-eastern region. The Amur wild carp is an ancient form that originated from the Asian carp (Amur-China type of wild carp, C. carpio haematopterus) which later spread to the water bodies of Western Asia. Over a period of hundreds of years, this carp got adapted to the local environmental conditions in the river Amur and got established in the river. It was brought into the gene bank of Fish Culture Research Institute, Hungary in 1982 (from the Russian National Fisheries Research Institute) where an improved breed of Amur common carp (Hugarian strain) was developed (Bakos and Gorda, 2001).

The local existing stock of common carp in India has several demerits as the fish attains maturity within six months and breeds naturally in the pond (Jhingran, 1982). This phenomenon retards growth through competition for food and space. Further in common carp; the gonads form $20-30 \%$ of body weight (Rao and Rao, 1983). To overcome these shortcomings, there have been attempts to produce all-male or sterile common carp population (Rao and Rao, 
1983; Das et al., 1990). Since the growth performance of the existing stock of common carp has been a major concern in the existing culture systems, the genetically improved breed of common carp, Amur (Hungarian strain) was introduced for the first time in Meghalaya during 2010-2011 to evaluate the performance of the breed under mid hill conditions.

\section{Materials and methods}

Growth studies in experimental systems

The seeds of improved breed of common carp - Amur (Hungarian strain) procured from Karnataka Veterinary, Animal and Fisheries Sciences University (KVAFSU), Hebbal, Bengaluru in early 2010 were stocked for monoculture in the fish farm complex of ICAR Research Complex for NEH Region (ICAR, RC NEHR), Barapani at different stocking densities for evaluating growth and reproductive performance under the mid hill conditions. Fish were fed regularly with rice polish and mustard oil cake (1:1 w/w)@2-3\% body weight. The fish attained an average weight of $794.5 \mathrm{~g}$ and a total length of $37.9 \mathrm{~cm}$ in a rearing period of 15 months under monoculture at a stocking density of 5000 nos. ha-1. In 2011, seeds produced from the parent stocks were further evaluated for growth performance and reproductive competence.

\section{Fecundity and seed production}

The fecundity of both Amur (Hungarian strain) and local common carp reared under mid altitude conditions was assessed during the months of September, December and March following standard procedures, as they attain full maturity during the month of February. Common carp is relatively easy to breed. Out of the total population of Amur common carp brood fish (population size: 200) maintained in the fish farm of the institute, only the healthy parents were selected and used at the ratio of 1 female : 2-3 males for hatchlings production using standard nylon hapa fixed in 0.40 ha stocking pond of the institute's fish farm. The fish attained full maturity in 13 months at an average size of $400 \mathrm{~g}$. The fish responded to the environmental conditions and laid adhesive eggs. No exogenous hormone was applied for breeding. Nylon rope filaments were used as substrate for egg attachment. On day 4 post-hatch, the spawn were transferred to well prepared nursery ponds $(0.02 \mathrm{ha})$ for fingerling production.

\section{On farm trial}

A total of 23 nos. of fish farmers' ponds covering a total pond area of 3.28 ha were selected in 8 villages viz., Kyrdemkulai, Kdonghulu, Liarbang, Lumblei, Bhoirymbong, Khlieh Mustem, Umroi and Liarkhla in the RiBhoi District of Meghalaya to evaluate the performance of Amur common carp in comparison to existing local common carp variety. Most of the ponds were small to medium in size ranging between 0.0158 to $0.44 \mathrm{ha}$. Seeds of Amur and local common carp ranging between 6-7 $\mathrm{cm}$ in length and 3-4 $\mathrm{g}$ in weight were stocked in the farmers' ponds during the months of June-July at three different stocking densities $(6,000$; 8,000 and 10,000 nos. ha ${ }^{-1}$ ) and cultured for a period of 232 to 236 days. The farmers were advised to feed the stocked fish regularly with rice polish, mustard oil cake or any locally available ingredients.

\section{Growth performance in composite fish culture}

To assess the growth of Amur common carp in composite fish culture system, another on farm trial was conducted in a farmer's ponds in Kyrdem Village of Ri-bhoi District in a water spread area of 0.06 ha during September 2011 to July 2012. The other two species stocked were grass carp and silver carp at a stocking density of 5,000 nos. ha- ${ }^{-1}$. The average initial stocking size of Amur common carp and local common carp were 9.25-10.25 g, while average weight of the other two species varied between 10.25-11.00 g. Fishes were fed with rice bran and mustard oil cake (1:1) twice (morning and evening).

\section{Results and discussion}

Growth and reproductive performance during experimental rearing

Water temperature, one of the important abiotic factors, controls various parameters in the life span of teleost fish (Das and Majhi, 2014). Under mid hill conditions at $900 \mathrm{~m}$ above msl, we recorded a minimum mean water temperature of $11.2^{\circ} \mathrm{C}$ in January and a maximum of $30.0^{\circ} \mathrm{C}$ during the month of July (Fig. 1). Thus, practically a period of only eight months in a year is conducive for the growth of carp fishes under mid hill condition. The Amur common carp seeds of initial average weight $14.5 \mathrm{~g}$ reared under monoculture at the institute fish farm complex attained maturity in about 13-14 months period attaining an average weight of $794.5 \mathrm{~g}$ (Fig. 2). Maximum weight of $1.5 \mathrm{~kg}$ was recorded during a culture period of 15 months. The best growth of Amur common carp was recorded from April to

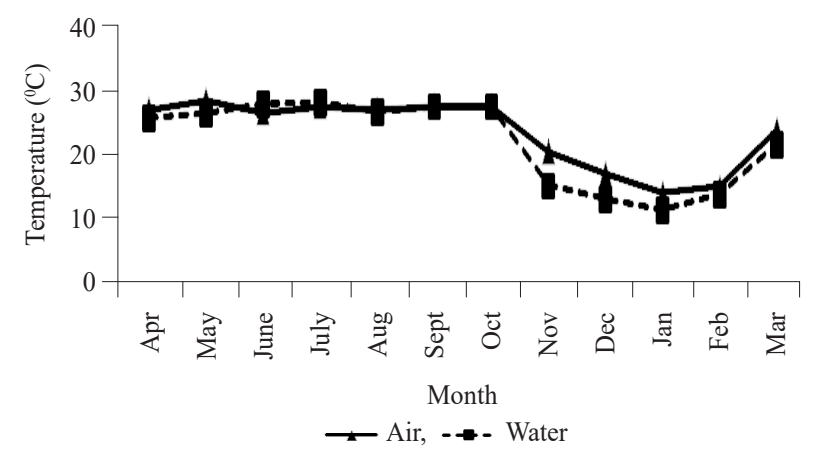

Fig. 1. Air and water temperature recorded at Fish farm complex, ICAR, RC NEHR Barapani, Meghalaya during April 2010 to March 2011 


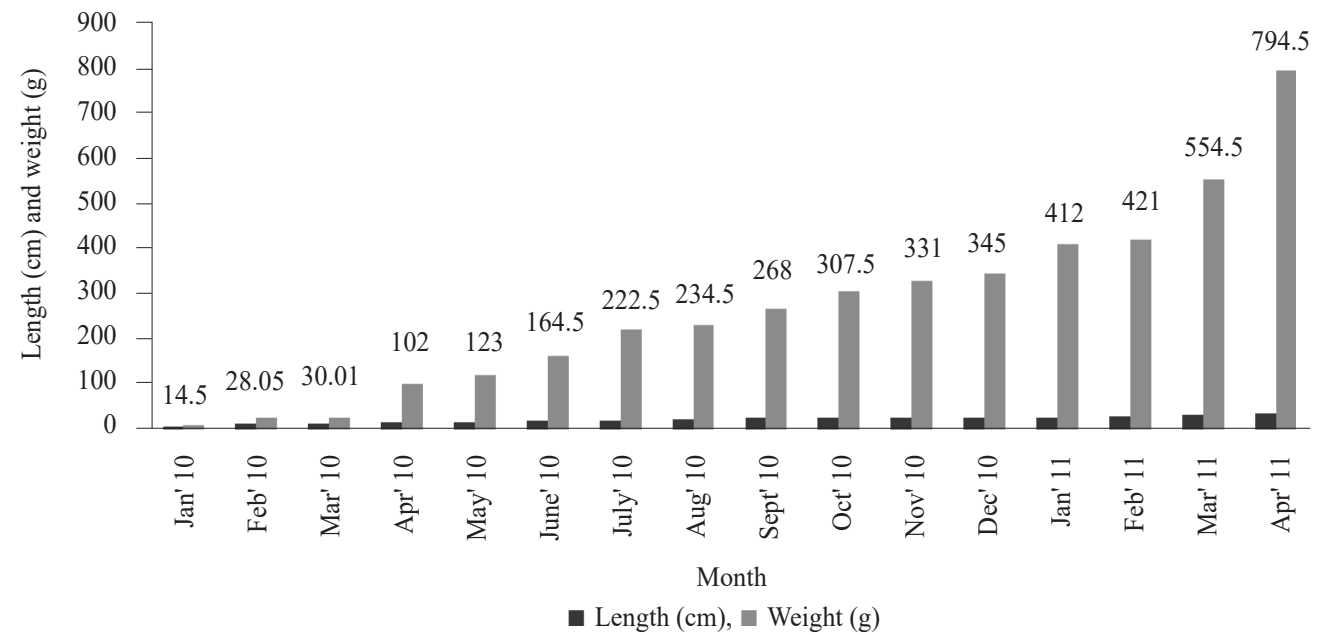

Fig. 2. Average growth of Amur common carp in 15 months under monoculture system in a 0.04 ha fish pond with stocking density of 5000 nos. ha-

August. To evaluate the growth performance during the winter months, Amur common carp seeds having initial size of $5.84 \mathrm{~cm}$ and $3.7 \mathrm{~g}$ were stocked in the farm pond of size 0.02 ha at a stocking density of 7,500 nos. ha ${ }^{-1}$ under monoculture system. The seeds attained an average size of $10.4 \mathrm{~cm}$ and $32.3 \mathrm{~g}$ in two months period (Dec - Feb).

In another trial, Amur common carp seeds produced at ICAR fish farm, Barapani in 2012 were stocked at a density of 6000 nos. ha-1 in a 0.04 ha fish pond under monoculture and an average growth of $\sim 200 \mathrm{~g}$ was obtained in 4 months rearing period (April-August). Fish were fed ad libitum with locally available feed ingredients, rice bran and mustard oil cake at 1:1 ratio. The period was observed to be the best for growth of fish under mid altitude condition.

In order to compare the growth performance of Amur common carp with that of local common carp, the seeds of both the varieties with initial average stocking size of $9.5 \mathrm{~g}$ were stocked at equal percentage at a stocking density of 8000 nos. ha-1 in a pond covering a water spread area of 0.02 ha. Amur common carp attained an average growth of $60 \mathrm{~g}$ while the local common carp attained an average growth of $45 \mathrm{~g}$ in a rearing period of 90 days during May to August. Fishes were fed with rice bran and mustard oil cake at 1:1 ratio daily (a) 3\% body weight. Optimal water quality parameters were maintained during the rearing period. The study revealed an enhanced weight gain of $33 \%$ in respect of Amur common carp over the local common carp.

\section{Fecundity}

The fecundity of both Amur and local common carp reared under mid altitude conditions was assessed during the months of September, December and March. The egg diameter of Amur common carp was observed to be slightly larger than the local common carp. The number of eggs per gram body weight as well as percentage of ovary weight to the body weight of Amur common carp was observed to be less than that of local common carp as shown in Table 1.

\section{Breeding}

Maiden attempt was made to breed the genetically improved variety of Amur common carp on a trial basis under mid hill conditions, in March 2011 when the atmospheric temperature varied between $16-18.3^{\circ} \mathrm{C}$. The female attained full maturity at the age of 14 months while the male matured earlier at the age of 9 months. Seeds of local common carp were also produced at the same time through hapa breeding to compare the growth with that of improved Hungarian strain. Initially, one set of genetically improved common carp comprising one fully mature female and three mature males were kept in hapa fixed in a 0.40 ha fish pond. The fertilised eggs took about $78-83 \mathrm{~h}$ to hatch. Water temperature ranged between $19-22.8^{\circ} \mathrm{C}$ while water $\mathrm{pH}$ varied between 6.5 and 6.8. Thereafter, several trials were conducted with one selected female and 2-3 males to produce seeds of the improved strain of common carp through simple hapa breeding method. February to April was observed to be the ideal spawning period under mid hill conditions with March being the peak period for seed production of Amur common carp.

\section{Onfarm trial}

Initially, the Amur common carp grew to an average size of $81.0 \mathrm{~g}$ while the local common carp strain registered an average growth of $47.50 \mathrm{~g}$ in a period of 101 days, in some of the farmer's ponds selected randomly. In onfarm trial, a maximum mean growth of $268 \mathrm{~g}(24.79 \mathrm{~cm})$ was recorded in Amur common carp against $199.5 \mathrm{~g}(20.53 \mathrm{~cm})$ of local common carp, registering an enhanced mean maximum 
Table 1. Comparison of fecundity of Amur common carp with local common carp

\begin{tabular}{|c|c|c|c|c|c|c|}
\hline \multicolumn{7}{|c|}{ Amur common carp } \\
\hline Length $(\mathrm{cm})$ & Weight (g) & $\begin{array}{l}\text { Wt. of } \\
\text { ovary (g) }\end{array}$ & $\begin{array}{l}\text { No. of eggs } \\
\text { per g ovary wt. }\end{array}$ & $\begin{array}{l}\text { Total no. of } \\
\text { eggs }\end{array}$ & $\begin{array}{l}\text { No. eggs per g } \\
\text { body wt. }\end{array}$ & $\begin{array}{l}\text { Percentage of ovary } \\
\text { wt. in body wt. }\end{array}$ \\
\hline 27.4 & 234.74 & 36.96 & 650 & 24,024 & 102.34 & 15.74 \\
\hline 27 & 225 & 25 & 720 & 18,000 & 80 & 11.11 \\
\hline 20.2 & 125.3 & 17.4 & 660 & 11,484 & 95.65 & 13.88 \\
\hline 19 & 93.9 & 12. & 670 & 8,308 & 88.47 & 13.2 \\
\hline \multirow[t]{2}{*}{20.6} & 138.05 & 26.7 & 880 & 23,496 & 170.19 & 19.34 \\
\hline & & & & Average \pm SD & $107.33 \pm 36.11$ & $14.654 \pm 3.09$ \\
\hline \multicolumn{7}{|c|}{ Local common carp } \\
\hline 27.7 & 220.24 & 25.24 & 1100 & 27,764 & 126.06 & 11.46 \\
\hline 26.9 & 214.74 & 34.66 & 1120 & 38,819 & 108.77 & 16.14 \\
\hline 25.4 & 207.4 & 30.7 & 1100 & 33,770 & 162.82 & 14.8 \\
\hline 23.1 & 134.5 & 15.5 & 1050 & 16,275 & 121.01 & 11.52 \\
\hline \multirow[t]{2}{*}{16.5} & 76.92 & 20.64 & 1080 & 22,291 & 289.79 & 26.83 \\
\hline & & & & Average \pm SD & $161.69 \pm 74.39$ & $16.15 \pm 6.31$ \\
\hline
\end{tabular}

growth of $34.33 \%$. While a mean minimum growth of $95.5 \mathrm{~g}(18.5 \mathrm{~cm})$ was recorded in Amur common carp, the local common carp demonstrated a mean minimum growth of $82.5 \mathrm{~g}(18.09 \mathrm{~cm})$, registering an enhanced mean minimum growth of $15.75 \%$ in Amur common carp during the rearing period. A stocking density ranging between 6,000 to 8,000 nos. ha ${ }^{-1}$ resulted in average 26 to $28 \%$ better growth in Amur common carp than the local common carp. The increase in weight of Amur common carp over the local common carp at stocking densities of 6,000 and 8,000 nos. ha ${ }^{-1}$ ranged between 17.09 to $37.59 \%$ with a mean increase of $26.71 \%$ (Fig. 3 and 4). Stocking density of 10,000 nos. ha-1 resulted in average growth increment of $21.97 \%$ in Amur common carp (Table 2 and Fig. 5).

\section{Growth performance in composite fish culture}

The water quality parameters monitored at monthly intervals were found to be within the optimal ranges. In 290 days of culture period, the Amur common carp attained an average weight of $500 \mathrm{~g}$ and $35 \mathrm{~cm}$ while the local common carp attained an average size of $440 \mathrm{~g}$ and $32.5 \mathrm{~cm}$.

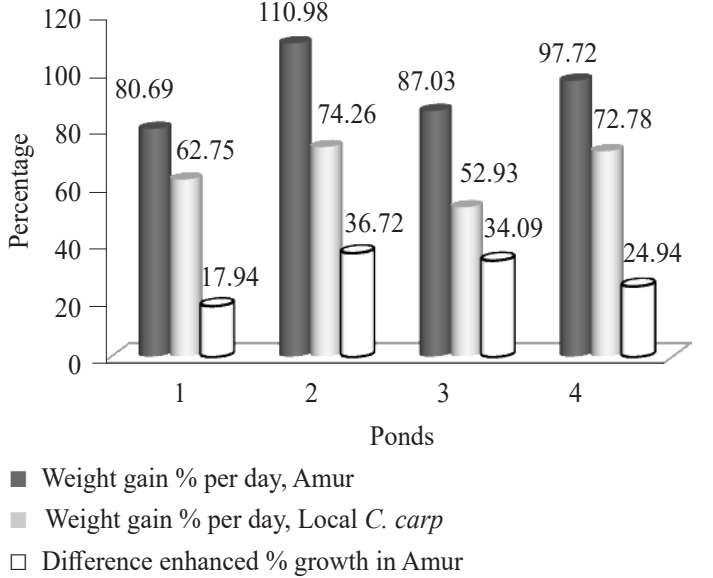

Fig. 3. Performance of Amur and local common carp in farmers' ponds at stocking density of 6,000 nos. ha ${ }^{-1}$

The Amur common carp demonstrated 13\% better growth than the existing local common carp in this on farm trial.

The growth of fish depends on several factors and temperature is an important factor that plays a significant

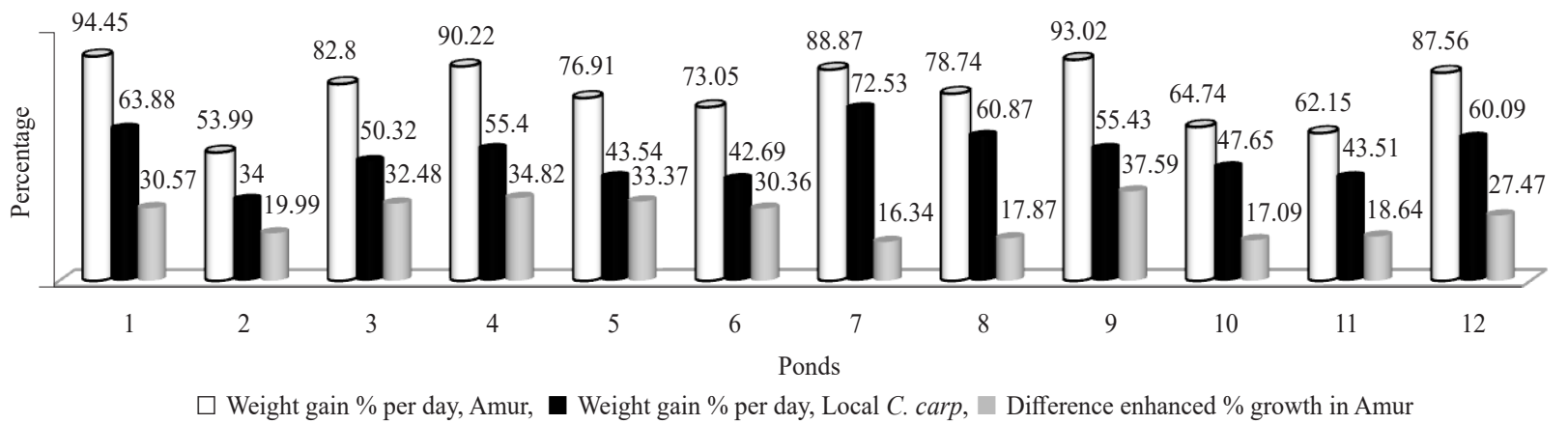

Fig. 4. Performance of Amur and local common carp in farmers' ponds at stocking density of 8,000 nos. ha' ${ }^{-1}$ 
Table 2. Growth performance of Amur common carp at different stocking densities in farmers' ponds

\begin{tabular}{|c|c|c|}
\hline Pond size (ha) & $\begin{array}{l}\text { Stocking } \\
\text { density }\left(\mathrm{ha}^{-1}\right)\end{array}$ & $\begin{array}{l}\text { Enhanced \% } \\
\text { growth in Amur } \\
\text { common carp }\end{array}$ \\
\hline 0.216 & 6,000 & 17.94 \\
\hline 0.1008 & 6,000 & 36.72 \\
\hline 0.0158 & 6,000 & 34.09 \\
\hline \multirow[t]{3}{*}{0.032} & 6,000 & 24.94 \\
\hline & Average & 28.42 \\
\hline & Std. Dev. & 8.62 \\
\hline 0.328 & 8,000 & 23.89 \\
\hline 0.104 & 8,000 & 30.57 \\
\hline 0.184 & 8,000 & 19.99 \\
\hline 0.184 & 8,000 & 32.48 \\
\hline 0.232 & 8,000 & 34.82 \\
\hline 0.1932 & 8,000 & 33.37 \\
\hline 0.28 & 8,000 & 30.36 \\
\hline 0.242 & 8,000 & 16.34 \\
\hline 0.44 & 8,000 & 17.87 \\
\hline 0.045 & 8,000 & 37.59 \\
\hline 0.025 & 8,000 & 17.09 \\
\hline 0.045 & 8,000 & 18.64 \\
\hline \multirow[t]{3}{*}{0.015} & 8,000 & 27.47 \\
\hline & Average & 26.19 \\
\hline & Std. Dev. & 7.54 \\
\hline 0.015 & 10,000 & 25.12 \\
\hline 0.144 & 10,000 & 18.94 \\
\hline \multirow[t]{3}{*}{0.192} & 10,000 & 21.86 \\
\hline & Average & 21.97 \\
\hline & Std. Dev & 3.091 \\
\hline
\end{tabular}

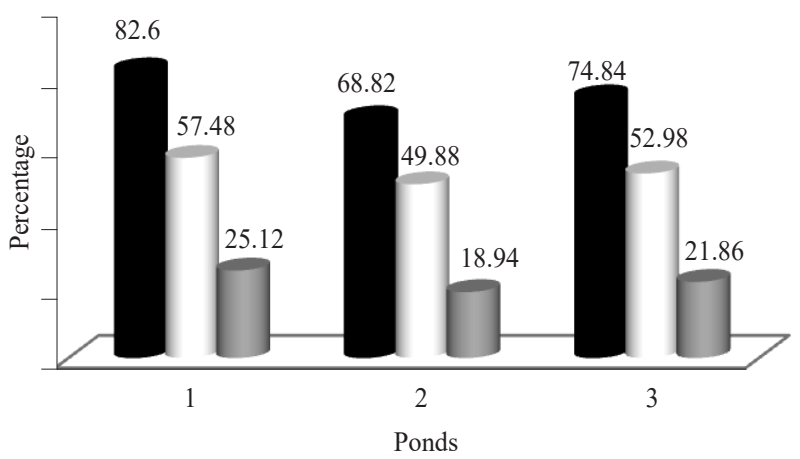

- Weight gain \% per day, Amur

- Weight gain \% per day, Local C. carp

- Difference enhanced \% growth in Amur

Fig. 5. Performance of Amur and local common carp in farmers' ponds at stocking density of 10,000 nos. ha ${ }^{-1}$ role in fish growth. Under mid altitude, a period of 6-8 months in a year has been found suitable for growth of carp species. The mean monthly water temperature of pond drops down to below $15^{\circ} \mathrm{C}$ during the period of November to February as shown in Fig. 1. Genetic quality, water quality, optimum stocking density and feed are also important factors affecting growth of fish in culture ponds. Although 33 fish ponds were selected and stocked for farmers' trial initially, only 23 ponds could be monitored for evaluation of growth performance. The growth performance of Amur common carp in comparison to local common carp was much higher during experimental trial in the Institute farm. In on farm trial, no feed was supplied to the participating farmers and the farmers were advised to feed the fish with locally available resources. Thus, the growth performance of Amur common carp in comparison to local common carp varied widely and in general, a moderate stocking density of 6000 nos. ha- ${ }^{-1}$ was observed to be more suitable for enhanced growth of Amur common carp in mid hill condition. In India, the performance of the Amur common carp was first evaluated in Bengaluru by Fisheries Research and Information Centre (Inland), KVAFSU, Hebbal (Basavaraju et al., 2003). The increase in weight of Amur over local stocks ranged from 13.2-50.1\% with increase of $27.3 \%$ (Basavaraju et al., 2005). It was also observed that the Amur stock did not spawn in culture tanks during 8 to 10 months culture period in Karnataka (Basavaraju et al., 2005). Similarly, the Amur common carp did not spawn naturally in culture ponds during 12 months of growing period while the local common carp has been observed to breed naturally in culture ponds at the age of 8 to 9 months under mid hill condition.

Since the improved variety has been found to mature late and grow faster resulting in higher flesh content, the fish production in the rural farmers' ponds is expected to increase. The information generated through the three year long project strongly suggests adoption of culture of improved variety of the common carp, Amur (Hungarian strain) especially in hilly region of the North-east India for enhancing fish production from farmers' ponds.

\section{Acknowledgements}

The author is grateful to the National Bank for Agriculture and Rural Development (R\&D) Mumbai, India for financial assistance, Dr. Y. Basavaraju, of KVAFSU, Hebbal, Bengaluru for providing the breeder's seeds of Amur common carp and Dr. S. V. Ngachan, Director of ICAR RC NEHR for providing facilities and encouragement.

\section{References}

Anon. 2012. Report on Meghalaya State Aquaculture Mission. Fish Farmers Development Agency, Govt. of Meghalaya, 156 pp. 
Bakos, J. and Gorda, S. 2001. Genetic resources of common carp at the Fish Culture Research Institute. Szarvas, Hungary. FAO Fisheries Technical Paper No. 417, Rome, Italy, 106 pp.

Basavaraju, Y., Penman, D. J. and Mair, G. C. 2003. Stock evaluation and development of a breeding program for common carp (Cyprinus carpio) in Karnataka, India: progress of a research project. $N A G A, 26(2): 30-32$.

Basavaraju, Y., Reddy, A. N. and Prashanth, N. Y. 2005. Amur common carp-Superior common carp breed released by KVAFSU, Bidar. Fisheries Research and Information Center (Inland) KVAFSU, Bengaluru, India.

Das, S. K. and Majhi, S. K. 2014. Low water temperature induces stress and affects somatic growth in teleost Channa stewartii (Perciformes). Aquac. Res., 1-5. doi:10.1111/are.12448

Das, S. K. and Ngachan, S. V. 2014. Introduction of two candidate fish species for mid hill aquaculture in Meghalaya. In: Souvenir, 10 $0^{\text {th }}$ Indian Fisheries and Aquaculture Forum,
12-15 November 2014. AFSIB, Mangalore, Karnataka and ICAR-NBFGR, Lucknow, Uttar Pradesh, p.111-113.

Das, S. K., Ngachan, S. V., Majhi, S. K., Murmu, K. and Das, A. 2010. Promotion of aquaculture through carp seed production under mid altitude condition in Meghalaya. In: Souvenir cum Abstract book, National consultation on biodiversity of high altitude aquatic resources, conservation and utilisation. Directorate of Coldwater Fisheries Research, ICAR, Bhimtal, Uttarakhand, p. 27-30.

Das, S. K., Shetty, H. P. C. and Nandeesha, M. C. 1990. Production of female-free common carp, Cyprinus carpio var. communis (L.) through dietary administration of the androgen Mibolerone. Asian Fish. Sci., 3: 197-203.

Jhingran, V. G. 1982. Fish and fisheries of India. Hindustan Publishing Corporation, Delhi.

Rao, H. N. S. and Rao, G. P. S. 1983. Hormonal manipulation of sex in the common carp, Cyprinus carpio var. communis (Linnaeus). Aquaculture, 35: 83-88. 